\title{
Excellent Performance of One-Pot Synthesized Cu-SSZ-13 Catalyst for the Selective Catalytic Reduction of $\mathrm{NO}_{x}$ with $\mathrm{NH}_{3}$
}

\author{
Lijuan Xie, ${ }^{\dagger}$ Fudong Liu, ${ }^{\dagger}$ Limin Ren, ${ }^{\ddagger}$ Xiaoyan Shi, ${ }^{\dagger}$ Feng-Shou Xiao, ${ }^{\S}$ and Hong $\mathrm{He}^{*}{ }^{\dagger}$ \\ ${ }^{\dagger}$ Research Center for Eco-Environmental Sciences, Chinese Academy of Sciences, Beijing 100085, China \\ ${ }^{\ddagger}$ College of Chemistry and State Key Laboratory of Inorganic Synthesis and Preparative Chemistry, Jilin University, Changchun \\ 130012, China \\ ${ }^{\S}$ Department of Chemistry, Zhejiang University, Hangzhou 310028, China
}

\section{Supporting Information}

ABSTRACT: Cu-SSZ-13 samples prepared by a novel one-pot synthesis method achieved excellent $\mathrm{NH}_{3}-\mathrm{SCR}$ performance and high $\mathrm{N}_{2}$ selectivity from 150 to $550{ }^{\circ} \mathrm{C}$ after ion exchange treatments. The selected $\mathrm{Cu}_{3.8}$-SSZ-13 catalyst was highly resistant to large space velocity $\left(800000 \mathrm{~h}^{-1}\right)$ and also maintained high $\mathrm{NO}_{x}$ conversion in the presence of $\mathrm{CO}_{2}, \mathrm{H}_{2} \mathrm{O}$, and $\mathrm{C}_{3} \mathrm{H}_{6}$ in the simulated diesel exhaust. Isolated $\mathrm{Cu}^{2+}$ ions located in three different sites were responsible for its excellent $\mathrm{NH}_{3}-\mathrm{SCR}$ activity. Primary results suggest that the one-pot synthesized Cu-SSZ-13 catalyst is a promising candidate as an $\mathrm{NH}_{3}-\mathrm{SCR}$ catalyst for the $\mathrm{NO}_{x}$ abatement from diesel vehicles.

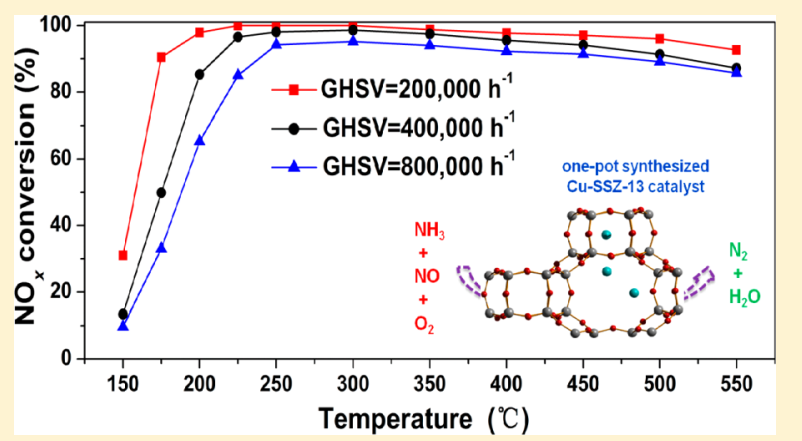

\section{INTRODUCTION}

Nitrogen oxides $\left(\mathrm{NO}_{x}\right)$, which result from automobile exhaust gas and industrial combustion of fossil fuels, is a major source of air pollution and can cause a series of environmental issues, such as photochemical smog and fine particle pollution (haze). Nowadays, the abatement of $\mathrm{NO}_{x}$ from diesel engines in oxygen-rich conditions remains a challenge in the field of environmental catalysis. The selective catalytic reduction of $\mathrm{NO}_{x}$ with $\mathrm{NH}_{3}\left(\mathrm{NH}_{3}-\mathrm{SCR}\right)$ is one of the most promising technologies for $\mathrm{NO}_{x}$ emission control from diesel engine exhaust. $\mathrm{WO}_{3}$ or $\mathrm{MoO}_{3}$ promoted $\mathrm{V}_{2} \mathrm{O}_{5} / \mathrm{TiO}_{2}$ catalysts and zeolite-supported base metal (e.g., $\mathrm{Cu}, \mathrm{Fe}$ ) catalysts are commonly used in SCR after-treatment converters to meet the diesel $\mathrm{NO}_{x}$ emission standards in the world. ${ }^{1-3}$ A typical diesel emission control system using SCR also includes a diesel particulate filter (DPF) which may expose the SCR catalysts to high temperatures $\left(>650{ }^{\circ} \mathrm{C}\right)$ during its regeneration. ${ }^{4}$ Traditional vanadium-based catalysts cannot remain active in such a temperature range due to the phase transformation of the $\mathrm{TiO}_{2}$ support. The toxicity of $\mathrm{V}_{2} \mathrm{O}_{5}$ to human health and the eco-environment is another important concern for its broad application on diesel engines. Although Fe-ZSM-5 and CuZSM-5 catalysts have been investigated extensively in recent years, some serious problems still remain to be resolved. For instance, on one hand, the activity of Fe-ZSM-5 in the low temperature range and the activity of $\mathrm{Cu}-\mathrm{ZSM}-5$ in the high temperature range need to be further increased. ${ }^{5}$ On the other hand, their activity always decreases significantly in the presence of water vapor at high temperatures due to the occurrence of dealumination, collapse of the zeolite structure, alteration of active metal species, and sintering of active metals. $^{6-9}$ Additionally, zeolite catalysts using ZSM-5 as support are sensitive to hydrocarbon poisoning owing to their intrinsically large pores and cages $(\sim 5.5 \AA$, tenmembered-ring), which are accessible to hydrocarbon deposition and coke formation. ${ }^{10-12}$ Therefore, it is imperative to develop improved catalyst materials with excellent $\mathrm{NH}_{3}-\mathrm{SCR}$ activity, high hydrothermal stability, and outstanding hydrocarbon poisoning resistance. Only such catalyst systems are qualified to respond to more stringent $\mathrm{NO}_{x}$ emission limits.

Recently, $\mathrm{Cu}$ /zeolite catalysts with chabazite ( $\mathrm{CHA}$ ) crystal structure became a promising candidate for $\mathrm{NH}_{3}-\mathrm{SCR}$ reaction, such as $\mathrm{Cu}-\mathrm{SAPO}-34$ and $\mathrm{Cu}-\mathrm{SSZ}-13 .{ }^{13-15} \mathrm{Cu}-\mathrm{SSZ}$ 13 prepared by an ion-exchange method showed improved activity, $\mathrm{N}_{2}$ selectivity, and hydrothermal stability compared with existing $\mathrm{Cu}-\mathrm{zeolite}$ catalysts, including $\mathrm{Cu}-\mathrm{ZSM}-5, \mathrm{Cu}-\mathrm{Y}$, and $\mathrm{Cu}$-beta. It achieved excellent $\mathrm{NO}_{x}$ conversion over the wide temperature range of $250-550{ }^{\circ} \mathrm{C}$, and the activity was maintained even after severe hydrothermal treatment at $800{ }^{\circ} \mathrm{C}$ for 16 h. ${ }^{8,9,16,17} \mathrm{CHA}$ structure contained eight-membered-ring pores $(3.8 \times 3.8 \AA)$ composed of six-membered rings in an AABBCC sequence. Such a small pore structure was expected to be more resistant to hydrocarbon poisoning. ${ }^{8}$ Isolated $\mathrm{Cu}^{2+}$ species located in the six-membered rings were confirmed to be the active sites in the $\mathrm{NH}_{3}-\mathrm{SCR}$ reaction over Cu-SSZ-13 catalyst. ${ }^{18-20} \mathrm{Kwak}$ proposed that $\mathrm{Cu}$ ions occupied sites in the large cages of the CHA structure at high ion exchange levels,

Received: July 20, 2013

Revised: December 1, 2013

Accepted: December 2, 2013

Published: December 2, 2013 
making them more easily reduced. ${ }^{2}$ Compared with other $\mathrm{Cu}$ / zeolites, Cu-SSZ-13 maintained the zeolite structure well and the active species maintained unchanged after severe hydrothermal aging. ${ }^{9}$ These characteristics indicate that a catalyst with such a structure could be a very promising candidate for practical application in $\mathrm{NO}_{x}$ emission control from diesel engines. However, the synthesis method of SSZ-13 zeolite reported by Zones in 1985 requires the very costly structuredirecting agent $N, N, N$-trimethyl-1-adamantammonium hydroxide (TMAdaOH), ${ }^{21,22}$ limiting the wide application of this material as a catalyst support. Therefore, it is desirable to improve the synthesis method to reduce the cost of Cu-SSZ-13 catalyst for the $\mathrm{NH}_{3}-\mathrm{SCR}$ process. More recently, Ren et al. designed a one-pot synthesis method of Cu-SSZ-13 catalyst using low-cost copper-tetraethylenepentamine ( $\mathrm{Cu}$-TEPA) as a novel template, which is beneficial to the wide use of $\mathrm{Cu}-\mathrm{SSZ}$ 13 catalyst. ${ }^{23}$ The product achieves high $\mathrm{Cu}$ loading and high dispersion of $\mathrm{Cu}$ species simultaneously. Compared with the conventional ion exchange method, the direct route introducing $\mathrm{Cu}^{2+}$ species into the zeolites greatly enhanced the efficiency of $\mathrm{Cu}$ species. More importantly, the obtained catalyst exhibits good $\mathrm{NH}_{3}-\mathrm{SCR}$ activity especially in the low temperature range. However, the activity needs to be further improved and much more work should be done to investigate this catalyst material in detail before its actual industrial application. In this study, we have further improved the synthesis method of $\mathrm{Cu}$ SSZ-13 catalyst and systemically investigated its catalytic performance in the $\mathrm{NH}_{3}-\mathrm{SCR}$ reaction under different working conditions. The improved method decreases the cost further and the optimal catalyst shows much better activity than the catalyst we have reported previously. ${ }^{23}$ The results suggest that the one-pot synthesized $\mathrm{Cu}$-SSZ-13 catalyst is a promising candidate for the $\mathrm{deNO}_{x}$ process of diesel engines.

\section{EXPERIMENTAL METHODS}

2.1. Catalyst Preparation. The catalyst was synthesized according to a procedure similar to that used for Cu-ZJM-1-10 as reported by Ren. ${ }^{23}$ Differently in this study, we adjusted the aluminosilicate gels to the mole ratio $14.8 \mathrm{Na}_{2} \mathrm{O}: 3.0 \mathrm{Al}_{2} \mathrm{O}_{3}: 600 \mathrm{H}_{2} \mathrm{O}: 30 \mathrm{SiO}_{2}: 4 \mathrm{Cu}-\mathrm{TEPA}$, using smaller amounts of reagents (the amount of $\mathrm{Cu}$-TEPA was reduced to $2 / 3$ of the original recipe) to obtain $\mathrm{CHA}$ structure. $\mathrm{Cu}$ source of $\mathrm{Cu}$-TEPA was $\mathrm{CuSO}_{4} \cdot 5 \mathrm{H}_{2} \mathrm{O}$. After crystallization at $140{ }^{\circ} \mathrm{C}$ for 4 days, the initial $\mathrm{Cu}-\mathrm{SSZ}-13$ product was obtained. Because the $\mathrm{Cu}$ content in the initial product was relatively high, an ion exchange method using $\mathrm{NH}_{4} \mathrm{NO}_{3}$ solution $(1 \mathrm{~mol} / \mathrm{L})$ was applied to obtain suitable $\mathrm{Cu}$ loadings. After ion exchange for 5 $\mathrm{h}$ once and twice, we obtained two Cu-SSZ-13 samples with different $\mathrm{Cu}$ loadings. Then, all samples were calcined at 600 ${ }^{\circ} \mathrm{C}$ for $6 \mathrm{~h}$ to remove the residual templates and denoted as $\mathrm{Cu}_{x}$-SSZ-13, where " $x$ " represents the $\mathrm{Cu}$ content in the catalyst by weight. The hydrothermal treatment of optimal catalyst was carried out with a gas condition of air and $10 \%$ $\mathrm{H}_{2} \mathrm{O}$ at $750{ }^{\circ} \mathrm{C}$ for $16 \mathrm{~h}$.

2.2. $\mathrm{NH}_{3}-\mathrm{SCR}$ Activity Measurement. SCR activity tests of the sieved powder catalysts were carried out in a fixed-bed quartz flow reactor at atmospheric pressure. The reaction conditions were controlled as follows: $500 \mathrm{ppm} \mathrm{NO}, 500 \mathrm{ppm}$ $\mathrm{NH}_{3}, 5$ vol $\% \mathrm{O}_{2}, 5$ vol \% $\mathrm{CO}_{2}$ (when used), 5 vol $\% \mathrm{H}_{2} \mathrm{O}$ (when used), 500 ppm $\mathrm{C}_{3} \mathrm{H}_{6}$ (when used), balance $\mathrm{N}_{2}$, and 500 $\mathrm{mL} / \mathrm{min}$ total flow rate. Different gas hourly space velocities (GHSVs) were obtained by changing the volume of catalysts. The effluent gas including $\mathrm{NO}, \mathrm{NH}_{3}, \mathrm{NO}_{2}$, and $\mathrm{N}_{2} \mathrm{O}$ was continuously analyzed by an online NEXUS 670-FTIR spectrometer equipped with a heated, low volume $(0.2 \mathrm{~L})$ multiple-path gas cell $(2 \mathrm{~m})$. The FTIR spectra were collected throughout and the results were recorded when the SCR reaction reached a steady state. Then, the $\mathrm{NO}_{x}$ conversion and $\mathrm{N}_{2}$ selectivity were calculated accordingly.

$$
\mathrm{NO}_{x} \text { conversion }=\left(1-\frac{[\mathrm{NO}]_{\text {out }}+\left[\mathrm{NO}_{2}\right]_{\text {out }}}{[\mathrm{NO}]_{\text {in }}+\left[\mathrm{NO}_{2}\right]_{\mathrm{in}}}\right) \times 100 \%
$$

$$
\begin{aligned}
\mathrm{N}_{2} \text { selectivity } & \frac{[\mathrm{NO}]_{\text {in }}+\left[\mathrm{NH}_{3}\right]_{\text {in }}-\left[\mathrm{NO}_{2}\right]_{\text {out }}-2\left[\mathrm{~N}_{2} \mathrm{O}\right]_{\text {out }}}{[\mathrm{NO}]_{\text {in }}+\left[\mathrm{NH}_{3}\right]_{\text {in }}} \\
& \times 100 \%
\end{aligned}
$$

2.3. Catalyst Characterization. The specific surface area and pore volume of $\mathrm{Cu}-\mathrm{SSZ}-13$ serial catalysts were obtained from $\mathrm{N}_{2}$ adsorption/desorption analysis at $77 \mathrm{~K}$ using a Quantachrome Quadrasorb SI-MP. Prior to the $\mathrm{N}_{2}$ physisorption, all samples were degassed at $300{ }^{\circ} \mathrm{C}$ for $5 \mathrm{~h}$. Micropore surface areas and micropore volumes were determined by $t$-plot method.

Powder X-ray diffraction (XRD) measurements were carried out on a computerized PANalytical X'Pert Pro diffractometer with $\mathrm{Cu} \mathrm{K} \alpha(\lambda=0.15406 \mathrm{~nm})$ radiation. The data of $2 \theta$ from $5^{\circ}$ to $40^{\circ}$ were collected with the step size of $0.02^{\circ}$.

The $\mathrm{Cu}$ contents of the catalysts were analyzed using an inductively coupled plasma instrument (OPTMIA 2000DV) with a radial view of the plasma. All samples were dissolved using strong acid solution before tested. The calibration solution was prepared using pure materials. The average of three atomic emission lines was used to determine the $\mathrm{Cu}$ contents in the catalysts.

The $\mathrm{H}_{2}$-TPR experiments were carried out on a Micromeritics AutoChem 2920 chemisorption analyzer. The samples $(50 \mathrm{mg})$ in a quartz reactor were pretreated at $500{ }^{\circ} \mathrm{C}$ in a flow of air $(50 \mathrm{~mL} / \mathrm{min})$ for $1 \mathrm{~h}$ and cooled down to the room temperature. Then $\mathrm{H}_{2}$-TPR was performed in $10 \mathrm{vol} \% \mathrm{H}_{2} / \mathrm{Ar}$ gas flow of $50 \mathrm{~mL} / \mathrm{min}$ at a heating rate of $10^{\circ} \mathrm{C} / \mathrm{min}$.

The EPR spectra of hydrated and dehydrated samples were recorded on a JEOL spectrometer at $123 \mathrm{~K}$. The JES FS200 software and the special JEOL program were used for data analysis. The fresh sample was pretreated at $500{ }^{\circ} \mathrm{C}$ for $2 \mathrm{~h}$ in 20 vol $\% \mathrm{O}_{2} / \mathrm{N}_{2}$ to prepare dehydrated sample. For measurement, all samples were placed into quartz tubes and evacuated in vacuum.

\section{RESULTS AND DISCUSSION}

3.1. Characterization of Catalysts. As shown in Figure 1, the initial $\mathrm{Cu}-\mathrm{SSZ}-13$ product exhibited the typical diffraction peaks of the CHA zeolite structure $\left(2 \theta=9.5^{\circ}, 14.0^{\circ}, 16.1^{\circ}\right.$, $17.8^{\circ}, 20.7^{\circ}$, and $\left.25.0^{\circ}\right)$ with a good degree of crystallization. ${ }^{24}$ The diffraction peaks for $\mathrm{CuO}\left(2 \theta=35.6^{\circ}\right.$ and $\left.38.8^{\circ}\right)$ and $\mathrm{Cu}_{2} \mathrm{O}\left(2 \theta=36.44^{\circ}\right)$ could not be identified. Therefore, the $\mathrm{Cu}$ species were dispersed very well in the initial Cu-SSZ-13 product. However, after calcination at $600{ }^{\circ} \mathrm{C}$, the diffraction peaks of $\mathrm{CuO}$ were clearly observed. This phenomenon indicates that the $\mathrm{Cu}$ loading was too high in the initial product, showing cations migration and transformation during the thermal treatment process. After treatment in $\mathrm{NH}_{4} \mathrm{NO}_{3}$ solution for $5 \mathrm{~h}$ once and twice and then calcination at $600{ }^{\circ} \mathrm{C}$, 


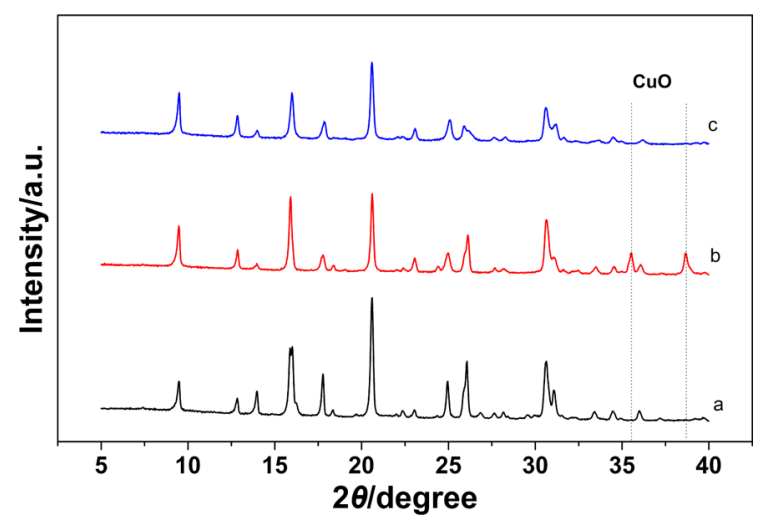

Figure 1. XRD patterns of the one-pot synthesized initial product and $\mathrm{Cu}_{x}$-SSZ-13 catalyst: (a) Initial product, (b) $\mathrm{Cu}_{10.3}-\mathrm{SSZ}-13$, (c) $\mathrm{Cu}_{3.8^{-}}$ SSZ-13.

the $\mathrm{Cu}$ loading of the catalyst decreased from $10.3 \mathrm{wt} \%$ to 3.8 wt $\%$ and 3.6 wt \%, respectively, and $\mathrm{Na}$ content decreased from 4.6 wt \% to $1.2 \mathrm{wt} \%$ and 0.7 wt \%, respectively (shown in Table 1). The diffraction peaks for $\mathrm{CuO}$ also disappeared in the

Table 1. Physicochemical Properties of $\mathrm{Cu}_{x}$-SSZ-13 Catalysts

\begin{tabular}{|c|c|c|c|c|c|}
\hline catalysts & $\begin{array}{l}S_{\text {micro }} \\
\left(\mathrm{m}^{2} / \mathrm{g}\right)\end{array}$ & $\begin{array}{l}V_{\text {micro }} \\
\left(\mathrm{cm}^{3} / \mathrm{g}\right)\end{array}$ & $\begin{array}{l}\mathrm{Si} / \mathrm{Al}_{2} \\
\text { ratio }\end{array}$ & $\begin{array}{c}\mathrm{Cu} \text { content } \\
\text { (wt \%) }\end{array}$ & $\begin{array}{l}\text { Na content } \\
\text { (wt \%) }\end{array}$ \\
\hline $\begin{array}{l}\mathrm{Cu}_{10.3^{-}} \\
\text {SSZZ-13 }\end{array}$ & 477.5 & 0.23 & 8.3 & 10.3 & 4.6 \\
\hline $\begin{array}{c}\mathrm{Cu}_{3.8} \text {-SSZ- } \\
13\end{array}$ & 525.7 & 0.26 & 8.3 & 3.8 & 1.2 \\
\hline $\begin{array}{l}\mathrm{Cu}_{3.6} \text {-SSZ- } \\
13\end{array}$ & 528.2 & 0.26 & 8.3 & 3.6 & 0.7 \\
\hline
\end{tabular}

XRD profile, because of removal of $\mathrm{Cu}$ outside of cages. The formation of $\mathrm{CuO}$ in $\mathrm{Cu}$-zeolite catalysts has been an important reason for the decrease of $\mathrm{NO}_{x}$ conversion in the high temperature range due to the occurrence of unselective catalytic oxidation of $\mathrm{NH}_{3}$ to $\mathrm{NO}_{x}$ in $\mathrm{NH}_{3}-\mathrm{SCR}$ process, which was demonstrated in previous studies. ${ }^{7}$ Therefore, the ion exchange treatment was very necessary to obtain Cu-SSZ-13 catalysts with appropriate $\mathrm{Cu}$ loadings in our study.

The results of the specific surface areas and pore volumes derived from $\mathrm{N}_{2}$ physisorption are summarized in Table 1 . Compared with $\mathrm{Cu}_{10.3}-\mathrm{SSZ}-13$, the surface area and pore volume of $\mathrm{Cu}_{3.8}-\mathrm{SSZ}-13$ increased from 477.5 to $525.7 \mathrm{~m}^{2} / \mathrm{g}$ and 0.23 to $0.26 \mathrm{~cm}^{3} / \mathrm{g}$, respectively. This increase should be associated with the disappearance of $\mathrm{CuO}$, which could block the pores of the SSZ-13 zeolite. It is noteworthy that there was no distinct difference in surface area and pore volume between $\mathrm{Cu}_{3.8}$-SSZ-13 and $\mathrm{Cu}_{3.6}$-SSZ-13 with similar $\mathrm{Cu}$ loading, although the latter catalyst was ion exchanged by $\mathrm{NH}_{4} \mathrm{NO}_{3}$ twice, indicating that one-time ion exchange was completely sufficient for the elimination of excess $\mathrm{Cu}$ species from the SSZ13 zeolite structure.

3.2. $\mathrm{NH}_{3}-\mathrm{SCR}$ Performance of Catalysts under Different Reaction Conditions. $\mathrm{NO}_{x}$ conversion as a function of reaction temperature between 150 and $550{ }^{\circ} \mathrm{C}$ over $\mathrm{Cu}-\mathrm{SSZ}-13$ catalysts with different $\mathrm{Cu}$ loadings is shown in Figure 2 . During the performance tests, about $50 \mathrm{mg}$ catalyst was used, yielding a rather high GHSV of $400000 \mathrm{~h}^{-1}$. The $\mathrm{Cu}_{10.3}$-SSZ-13 catalyst with the highest $\mathrm{Cu}$ loading exhibited the lowest performance compared with the others. Because of the formation of $\mathrm{CuO}$, the $\mathrm{NO}_{x}$ conversion decreased rapidly

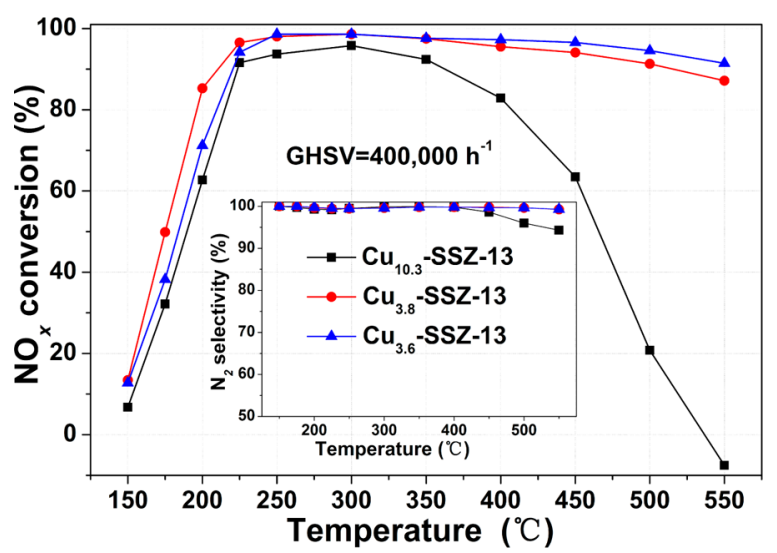

Figure 2. $\mathrm{NO}_{x}$ conversions and $\mathrm{N}_{2}$ selectivity over $\mathrm{Cu}_{x}-\mathrm{SSZ}-13$ catalysts.

when the temperature was above $400{ }^{\circ} \mathrm{C}$. $\mathrm{CuO}$ was unrelated to the SCR activity in the low temperature range, and decreased the activity in the high temperature range seriously due to the overoxidation of $\mathrm{NH}_{3}{ }^{25,26}$ Thus, elimination of $\mathrm{CuO}$ was necessary to prepare better catalysts. For $\mathrm{Cu}_{3.8} \mathrm{SSZ}-13$ with appropriate $\mathrm{Cu}$ loading, the $\mathrm{NO}_{x}$ conversion was further improved over the whole temperature range, reaching $c a .85 \%$ at $200{ }^{\circ} \mathrm{C}$ and maintaining a level above $90 \%$ until $550{ }^{\circ} \mathrm{C}$. For the $\mathrm{Cu}_{3.6^{-}}$SSZ-13 catalyst with $\mathrm{Cu}$ content similar to $\mathrm{Cu}_{3.8^{-}}$SSZ13 , a slight decline was observed in the SCR performance over the whole temperature range. Furthermore, excellent $\mathrm{N}_{2}$ selectivity over both $\mathrm{Cu}_{3.8^{-}}$SSZ-13 and $\mathrm{Cu}_{3.6}$-SSZ-13 catalysts could be obtained, at nearly $100 \%$ from 150 to $550{ }^{\circ} \mathrm{C}$ and relatively higher than that over the $\mathrm{Cu}_{10.3}$-SSZ-13 catalyst. In short, the ion exchange by $\mathrm{NH}_{4} \mathrm{NO}_{3}$ is an important treatment procedure for obtaining an excellent $\mathrm{Cu}-\mathrm{SSZ}-13$ catalyst with high SCR performance and $\mathrm{N}_{2}$ selectivity simultaneously, and one-time exchange is sufficient to produce a suitable catalyst for the $\mathrm{NH}_{3}-\mathrm{SCR}$ reaction. Additionally, deNO $\mathrm{N}_{x}$ catalytic activities of $\mathrm{Cu}_{3.8}$-SSZ-13 catalyst at 600,650 , and $700{ }^{\circ} \mathrm{C}$ were also tested because the instantaneous temperature can be up to $600-700{ }^{\circ} \mathrm{C}$ in the real diesel exhaust (Table S1). The results indicate that the catalyst could also maintain good $\mathrm{NH}_{3}-\mathrm{SCR}$ performance in such a high temperature range. Figure 3 shows the $\mathrm{NO}_{x}$ conversions over the $\mathrm{Cu}_{3.8}$-SSZ-13 catalyst under

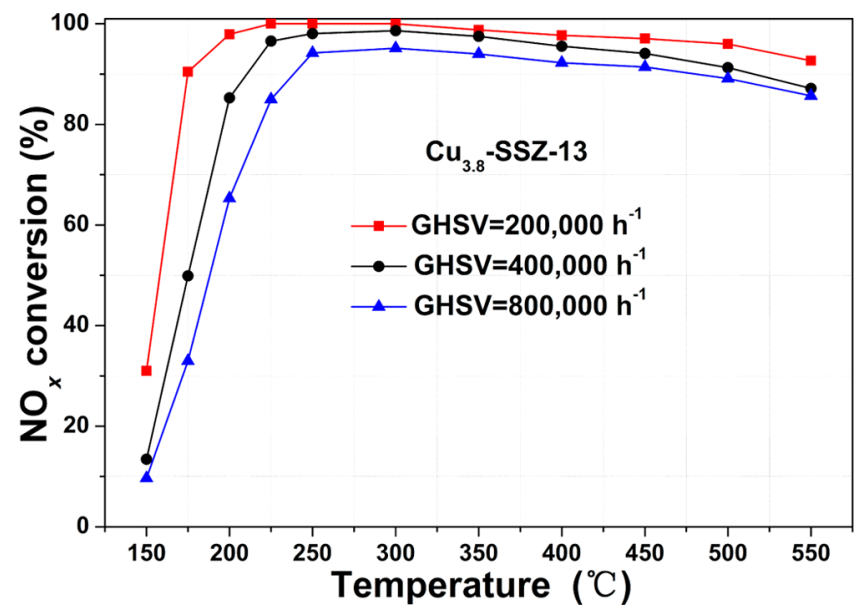

Figure 3. $\mathrm{NO}_{x}$ conversions over $\mathrm{Cu}_{3.8}$-SSZ-13 catalyst under different GHSVs. 
different GHSVs. It is clear that the increase of GHSV from 200000 to $400000 \mathrm{~h}^{-1}$ resulted in the decrease of $\mathrm{NH}_{3}-\mathrm{SCR}$ performance to a certain extent at low temperatures especially below $200{ }^{\circ} \mathrm{C}$, yet there was no distinct effect on the high temperature SCR performance. Remarkably, the $\mathrm{Cu}_{3.8}$-SSZ-13 catalyst showed rather high $\mathrm{NO}_{x}$ conversions exceeding $90 \%$ within a broad operation temperature window from 250 to 550 ${ }^{\circ} \mathrm{C}$ even under an extremely high GHSV of $800000 \mathrm{~h}^{-1}$, suggesting that this catalyst is highly resistant to the effects of large space velocity. This characteristic is crucial for its practical application in diesel vehicles with limited installation space on board for a SCR after-treatment converter.

As the composition of diesel exhaust is complicated, we further tested the $\mathrm{NH}_{3}-\mathrm{SCR}$ performance of the $\mathrm{Cu}_{3.8}$-SSZ-13 catalyst in the presence of $\mathrm{CO}_{2}, \mathrm{H}_{2} \mathrm{O}$, and $\mathrm{C}_{3} \mathrm{H}_{6}$ under the GHSV of $400000 \mathrm{~h}^{-1}$, with the results shown in Figure 4.

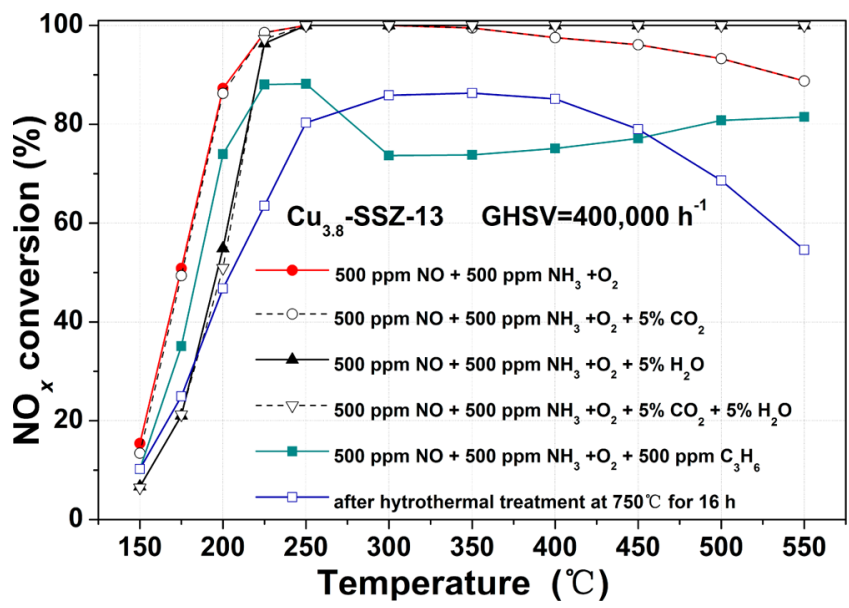

Figure 4. $\mathrm{NO}_{x}$ conversions over $\mathrm{Cu}_{3.8}$-SSZ-13 catalyst under different reaction conditions.

There was no inhibition effect on $\mathrm{NH}_{3}-\mathrm{SCR}$ performance observed at all when $5 \% \mathrm{CO}_{2}$ was present in the feed gas. By comparison, the presence of $5 \% \mathrm{H}_{2} \mathrm{O}$ decreased the $\mathrm{NO}_{x}$ conversion significantly at low temperatures $\left(<200{ }^{\circ} \mathrm{C}\right)$ mainly due to the competitive adsorption by $\mathrm{H}_{2} \mathrm{O}$ adsorption and increased the $\mathrm{NO}_{x}$ conversion at high temperatures $\left(>400{ }^{\circ} \mathrm{C}\right)$ probably due to the inhibition effect of $\mathrm{H}_{2} \mathrm{O}$ on the unselective catalytic oxidation of $\mathrm{NH}_{3}{ }^{27,28}$ It was also demonstrated that there was no synergistic inhibition effect on SCR performance in the coexistence of $\mathrm{CO}_{2}$ and $\mathrm{H}_{2} \mathrm{O}$. The presence of $500 \mathrm{ppm}$ $\mathrm{C}_{3} \mathrm{H}_{6}$ inhibited the $\mathrm{NH}_{3}$-SCR reactions especially around 300 ${ }^{\circ} \mathrm{C}$, probably due to the partial oxidation of $\mathrm{C}_{3} \mathrm{H}_{6}$ (Figure $\mathrm{S} 1$ ). ${ }^{10}$ The $\mathrm{NO}_{x}$ conversion increased in the high temperature range at around $400{ }^{\circ} \mathrm{C}$, which should be related to the occurrence of HC-SCR during the $\mathrm{NH}_{3}-\mathrm{SCR}$ reaction (Figure S2). ${ }^{11,19}$ Compared with other $\mathrm{Cu}$ /zeolites and $\mathrm{Fe}$ /zeolites, $\mathrm{Cu}-\mathrm{SSZ}-13$ exhibits better $\mathrm{C}_{3} \mathrm{H}_{6}$ poisoning resistance. ${ }^{11,29}$ After hydrothermal treatment at $750{ }^{\circ} \mathrm{C}$ for $16 \mathrm{~h}$, the $\mathrm{NO}_{x}$ conversion maintained higher than $80 \%$ from 250 to $450{ }^{\circ} \mathrm{C}$, indicating its good hydrothermal stability. The XRD profile of aged $\mathrm{Cu}_{3.8^{-}}$ SSZ-13 sample showed that the CHA structure was still maintained, although a small amount of amorphous phase appeared (Figure S3). Both the structural stability of the zeolite and the $\mathrm{Cu}$ species stability could affect the hydrothermal stability of the catalyst. It is well-known that the bonds of $\mathrm{Si}-$ $\mathrm{O}-\mathrm{Al}$ were less stable than those of $\mathrm{Si}-\mathrm{O}-\mathrm{Si}$ and dealumination occurred via attack of $\mathrm{Si}-\mathrm{O}-\mathrm{Al}$ by $\mathrm{H}_{2} \mathrm{O}$. ${ }^{6}$ The damage of structure aroused by dealumination was fatal for catalysts. ${ }^{27} \mathrm{Al} \mathrm{NMR}$ profile of aged $\mathrm{Cu}_{3.8}$-SSZ-13 sample indicated the occurrence of dealumination during the hydrothermal treatment (Figure S4), which should be the main reason for its decreased NO conversion. Thus, it is positive to improve the $\mathrm{Si} / \mathrm{Al}_{2}$ ratio for further improvement of the hydrothermal stability of the catalyst. The influence of $\mathrm{Cu}$ species stability will be discussed below.

3.3. Distribution of $\mathrm{Cu}$ Species in Cu-SSZ-13 Catalyst. $\mathrm{H}_{2}$-TPR profiles of $\mathrm{Cu}_{10.3^{-}} \mathrm{SSZ}-13, \mathrm{Cu}_{3.8^{-}} \mathrm{SSZ}-13$, and $\mathrm{Cu}_{3.6^{-}}$ SSZ-13 are shown in Figure 5a. $\mathrm{No}_{2}$ consumption could be
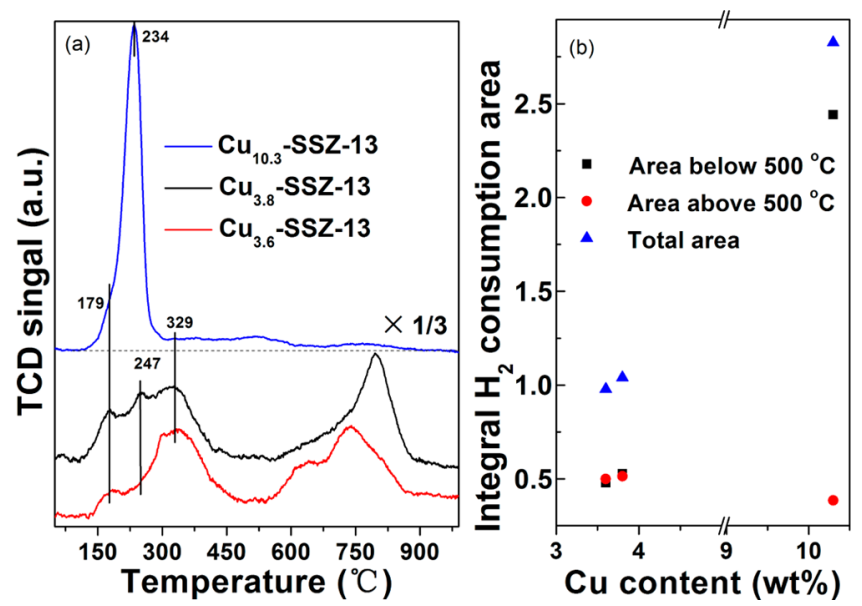

Figure 5. $\mathrm{H}_{2}$-TPR profiles of $\mathrm{Cu}_{10.3}$-SSZ-13, $\mathrm{Cu}_{3.8}$-SSZ-13, and $\mathrm{Cu}_{3.6}$ SSZ-13 catalysts (a); integrated $\mathrm{H}_{2}$ consumption areas as a function of $\mathrm{Cu}$ loading in different temperature range (b).

observed for H-SSZ-13 (Figure S5), which proved that all $\mathrm{H}_{2}$ consumption peaks in the $\mathrm{H}_{2}$-TPR profiles of $\mathrm{Cu}-\mathrm{SSZ}-13$ catalysts were due to the reduction of $\mathrm{Cu}$ species. $\mathrm{H}_{2}-\mathrm{TPR}$ is an effective method to identify dimeric and $\mathrm{CuO}$ cluster from isolated $\mathrm{Cu}^{2+}$ due to the more facile reduction of them. In previous studies, the one-step reduction of dispersed bulk $\mathrm{CuO}$ to $\mathrm{Cu}^{0}$ occurred in the temperature range $\left(200-300{ }^{\circ} \mathrm{C}\right) .{ }^{30}$ Similar with $\mathrm{CuO},[\mathrm{Cu}-\mathrm{O}-\mathrm{Cu}]^{2+}$ dimers also could be reduced to $\mathrm{Cu}^{0}$ in the temperature range below $800 \mathrm{~K}^{31}$ Differently, reduction of isolated $\mathrm{Cu}^{2+}$ in zeolites has been proposed to occur by a two-step mechanism, namely, the reduction from $\mathrm{Cu}^{2+}$ to $\mathrm{Cu}^{+}$(at low temperatures) and the reduction from $\mathrm{Cu}^{+}$to $\left.\mathrm{Cu}^{0}(>800 \mathrm{~K})\right)^{32}$ Thus, the $\mathrm{H}_{2}$ consumption areas below $500{ }^{\circ} \mathrm{C}$ and the areas above 500 ${ }^{\circ} \mathrm{C}$ were calculated for all three catalysts. As shown in Figure 5 b, a very large amount of $\mathrm{H}_{2}$ consumption area was observed below $500{ }^{\circ} \mathrm{C}$ for $\mathrm{Cu}_{10.3}$-SSZ-13 catalyst, suggesting that not only the reduction from $\mathrm{Cu}^{2+}$ to $\mathrm{Cu}^{+}$but also the reduction from $\mathrm{Cu}^{+}$to $\mathrm{Cu}^{0}$ occurred before $500{ }^{\circ} \mathrm{C}$. The XRD pattern proved the existence of $\mathrm{CuO}$ in the $\mathrm{Cu}_{10.3}$-SSZ-13 catalyst (Figure 1). Therefore, the large peak at $234{ }^{\circ} \mathrm{C}$ observed for the $\mathrm{Cu}_{10.3}$-SSZ-13 catalyst should be caused by the dispersed $\mathrm{CuO}$ to a large extent. However, the integral $\mathrm{H}_{2}$ consumption areas below and above $500{ }^{\circ} \mathrm{C}$ were equal for both $\mathrm{Cu}_{3.8}$-SSZ-13 and $\mathrm{Cu}_{3.6}$-SSZ-13 catalysts (Figure $5 \mathrm{~b}$ ), meaning no $\mathrm{Cu}^{0}$ formed below $500{ }^{\circ} \mathrm{C}$. Thus, the existence of $\mathrm{CuO}$ or $[\mathrm{Cu}-\mathrm{O}-\mathrm{Cu}]^{2+}$ dimers were excluded safely, and only isolated $\mathrm{Cu}^{2+}$ existed in the two catalysts. Therefore, three apparent reduction peaks (ca. 179,247 , and $329^{\circ} \mathrm{C}$ ) for the $\mathrm{Cu}_{3.8}$-SSZ-13 catalyst could be assigned to the reduction of isolated $\mathrm{Cu}^{2+}$ to $\mathrm{Cu}^{+}$. The easy reducibility of isolated $\mathrm{Cu}^{2+}$ ions (the reduction temperature 
was as low as $179^{\circ} \mathrm{C}$ ) was responsible for the excellent $\mathrm{NH}_{3}-$ SCR performance in the low temperature range.

It is well-known that there are four types of cationic sites in chabazite. Site I is displaced from the six-membered-ring into the ellipsoidal cavity. Site II is located near the center of the ellipsoidal cavity. Site III is located in the center of the hexagonal prism. Site IV is located near the eight-memberedring window. ${ }^{33,34}$ Isolated $\mathrm{Cu}^{2+}$ ions locating at different cationic sites should show different $\mathrm{H}_{2}$ reduction temperatures. In order to better assign the reduction peaks, EPR experiments were carried out for the selective $\mathrm{Cu}_{3.8}$-SSZ-13 catalyst. EPR was an excellent technique for identifying the coordination environment of isolated $\mathrm{Cu}^{2+}$ ions, because all the other $\mathrm{Cu}$ species $\left(\mathrm{Cu}-\mathrm{O}-\mathrm{Cu}\right.$ or $\left.\mathrm{Cu}^{+}\right)$were EPR silent. ${ }^{34,35}$ Both EPR spectra of hydrated and dehydrated $\mathrm{Cu}_{3.8}$-SSZ-13 samples were collected in this study (Figure 6a).

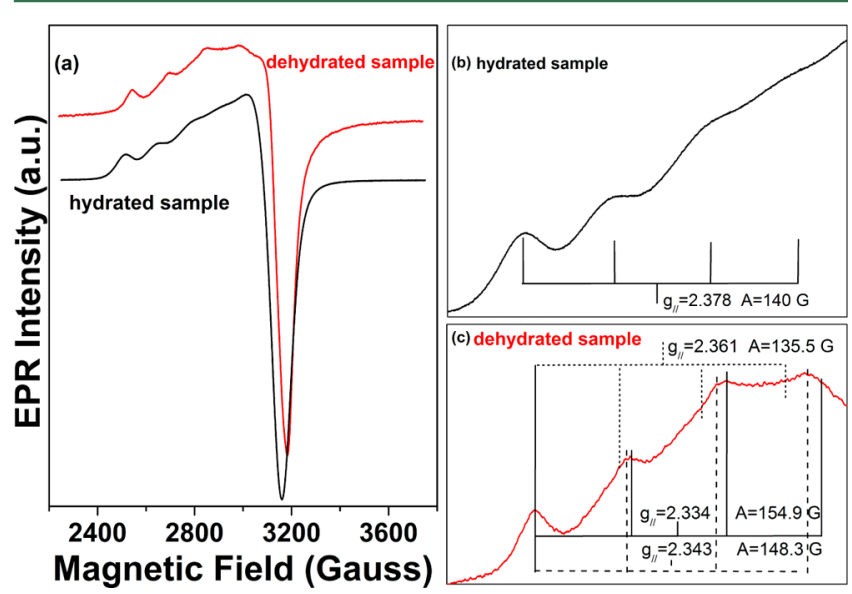

Figure 6. EPR spectra of $\mathrm{Cu}_{3.8}$-SSZ-13 catalyst recorded at $123 \mathrm{~K}$. (a) Hydrated sample (dark line) and dehydrated sample (red line). Analysis of the hyperfine features of hydrated sample (b) and dehydrated sample (c).

By analyzing the hyperfine features of the hydrated sample (Figure $6 \mathrm{~b}$ ), $g_{/ /}=2.378$ and $A=140 \mathrm{G}$ was obtained. Zamadics et al. reported that EPR signal $\left(g_{/ /}=2.381, A=143 \mathrm{G}\right)$ in hydrated $\mathrm{Cu}$-SAPO-34 could be assigned to $\mathrm{Cu}^{2+}$ located in site I as a complex $\mathrm{Cu}\left(\mathrm{O}_{\mathrm{F}}\right)_{3}\left(\mathrm{H}_{2} \mathrm{O}\right)_{3}{ }^{34}$ The similar EPR signals for $\mathrm{Cu}$-CHA catalysts reported by others were also suggested to be this type of species, such as $g_{/ /}=2.39$ with $A=111 \mathrm{G}$ and $g_{/ /}=$ 2.394 with $A=131 \mathrm{G}^{25,31}$ Thus, this EPR signal should be due to the isolated $\mathrm{Cu}^{2+}$ located in site I for hydrated $\mathrm{Cu}_{3.8}$-SSZ-13 catalyst $\left(\mathrm{Cu}_{\mathrm{I}}^{2+}\right) \cdot{ }^{34,31}$ Because isolated $\mathrm{Cu}^{2+}$ species could migrate from one site to another upon thermal treatment, the dehydrated sample always contained more types of $\mathrm{Cu}$ species than the hydrated sample. ${ }^{34}$ The similar phenomenon was also observed for the $\mathrm{Cu}_{3.8}$-SSZ-13 catalyst, and three distinct $\mathrm{Cu}^{2+}$ species were discovered from the three sets of parameters determined from the EPR signal for the dehydrated sample (Figure 6c). Narayana et al. reported that the $\mathrm{Cu}^{2+}$ in site I with trigonal environment for dehydrated sample showed EPR signal of $g_{/ /}=2.379$ with $A=133 \mathrm{G}^{36}$ In addition, Herman et al. proved that EPR signals of $\mathrm{Cu}^{2+}$ with trigonal environment varied with different $\mathrm{Cu}$ loading and different evacuation time in dehydration process, and the signals from $g_{/ /}=2.36$ with $A=$ $125 \mathrm{G}$ to $g_{/ /}=2.38$ with $A=110 \mathrm{G}$ were recorded. ${ }^{37}$ Thus, the first species for dehydrated sample giving rise to the $g_{/ /}=2.361$ and $A=135.5 \mathrm{G}$ (Figure $6 \mathrm{c}$ ) in $\mathrm{Cu}_{3.8}$-SSZ-13 could be assigned to $\mathrm{Cu}^{2+}$ located in site $\mathrm{I}\left(\mathrm{Cu}^{2+}\right){ }^{34,36}$

$\mathrm{Yu}$ et al. reported that the species located in hexagonal prism (site III) showed EPR single at $g_{/ 6}=2.335$ with $A=155 \mathrm{G}$ base on a lack of oxygen broadening. ${ }^{38}$ Zamadics et al. also assigned the EPR single of $g_{/ /}=2.336$ with $A=168 \mathrm{G}$ to $\mathrm{Cu}$ species in site III. ${ }^{34}$ Thus, the second species with $g_{/ /}=2.334$ and $A=$ 154.9 $\mathrm{G}$ in this study could be assigned to isolated $\mathrm{Cu}^{2+}$ species located in site III $\left(\mathrm{Cu}^{2+} \mathrm{III}\right){ }^{34}$ Xue et al. proved that the $\mathrm{H}_{2}$ reduction peak at ca. $250-260{ }^{\circ} \mathrm{C}$ was aroused from $\mathrm{Cu}^{2+}{ }_{\mathrm{I}}$ perfectly. ${ }^{25}$ Thus, the $\mathrm{H}_{2}$ reduction peak at $247{ }^{\circ} \mathrm{C}$ was attributed to $\mathrm{Cu}^{2+}$. Isolated $\mathrm{Cu}^{2+}$ ions locating in site III with higher coordination number, which are more difficult to be reduce, are more stable than the $\mathrm{Cu}^{2+}$ ions locating in site $\mathrm{I}^{2}$ Thus, the reduction peak at $329^{\circ} \mathrm{C}$ should be caused by the $\mathrm{Cu}^{2+}$ III. Besides of $\mathrm{Cu}^{2+}$ species locating in the sites I and III, the third $\mathrm{Cu}^{2+}$ species with $g_{/ /}=2.343$ and $A=148.3 \mathrm{G}$ could occupy site II or IV in the chabizite structure. However, site II is occupied only in hydrated chabazite. ${ }^{33,40}$ Thus, the third type of species could be assigned to the isolated $\mathrm{Cu}^{2+}$ locating in site IV. It was reported that the isolated $\mathrm{Cu}^{2+}$ ions occupying site IV were much easier to reduce than those locating in site I; therefore, it is reasonable that the reduction peak at ca. $179{ }^{\circ} \mathrm{C}$ is caused by isolated $\mathrm{Cu}^{2+}$ ions in site IV $\left(\mathrm{Cu}_{\text {Iv }}^{2+}\right)_{.}^{2,41}$ In summary, the $\mathrm{H}_{2}$ reduction peaks at 179,247 , and $329^{\circ} \mathrm{C}$ for dehydrated $\mathrm{Cu}_{3.8}$-SSZ-13 catalyst were attributed to isolated $\mathrm{Cu}^{2+}$ ions locating in site IV, I, and III of chabizite structure, respectively.

It is known that $\mathrm{Cu}^{2+}$ species located in site III was less active than species in site I in $\mathrm{NH}_{3}-\mathrm{SCR}$ reaction due to steric hindrance. $^{39}$ The conclusion is proven in this study, as shown below. Figure 5 shows that the distribution of $\mathrm{Cu}$ species was changed during the second $\mathrm{NH}_{4} \mathrm{NO}_{3}$ treatment. More $\mathrm{Cu}^{2+}$ species were observed in $\mathrm{Cu}_{3.6}$-SSZ-13 than $\mathrm{Cu}_{3.8}$-SSZ-13 from $\mathrm{H}_{2}$-TPR profiles, and poorer activity was observed in the low temperature range for $\mathrm{Cu}_{3.6}$-SSZ-13 catalyst (Figure 2). Thus, the ratio of $\left(\mathrm{Cu}^{2+}{ }_{\mathrm{I}}+\mathrm{Cu}^{2+}{ }_{\mathrm{IV}}\right) / \mathrm{Cu}^{2+}{ }_{\text {III }}$ play an important role for $\mathrm{NH}_{3}-\mathrm{SCR}$ reaction over $\mathrm{Cu}-\mathrm{SSZ}-13$ catalyst prepared by onepot synthesis method. It was reported that the reduction of $\mathrm{Cu}^{+}$ species to $\mathrm{Cu}^{0}$ was expected when the $\mathrm{CHA}$ structure begin to degrade. ${ }^{31}$ The higher reduction temperature from $\mathrm{Cu}^{+}$to $\mathrm{Cu}^{0}$ represents the better stability of the species. Compared with $\mathrm{Cu}_{3.8}$-SSZ-13, the reduction temperature was much lower for $\mathrm{Cu}_{3.6}$-SSZ-13 catalyst (Figure 5). The $\mathrm{NH}_{3}-\mathrm{SCR}$ performance of aged $\mathrm{Cu}_{3.6}$ SSZ-13 catalyst was much poorer (Figure S6). Thus, the high hydrothermal stability of $\mathrm{Cu}_{3.8}$-SSZ-13 catalyst is relative to its high stability of $\mathrm{Cu}$ species.

\section{ASSOCIATED CONTENT}

\section{S Supporting Information}

$\mathrm{NH}_{3}$-SCR activity at high temperatures, effect of $\mathrm{C}_{3} \mathrm{H}_{6},{ }^{27} \mathrm{Al}$ $\mathrm{NMR}$ and $\mathrm{XRD}$ profiles for aged $\mathrm{Cu}_{3.8}$-SSZ-13, $\mathrm{NH}_{3}-\mathrm{SCR}$ activity of aged $\mathrm{Cu}_{3.6}$-SSZ-13. This material is available free of charge via the Internet at http://pubs.acs.org.

\section{AUTHOR INFORMATION}

\section{Corresponding Author}

*Fax: +86 10 62849123; Tel: +86 10 62849123; E-mail: honghe@rcees.ac.cn.

\section{Notes}

The authors declare no competing financial interest. 


\section{ACKNOWLEDGMENTS}

This work was financially supported by the National Natural Science Foundation of China (51278486), the National High Technology Research and Development Program of China (2013AA065301).

\section{REFERENCES}

(1) Roy, S.; Hegde, M. S.; Madras, G. Catalysis for $\mathrm{NO}_{x}$ abatement. Appl. Energy 2009, 86 (11), 2283-2297.

(2) Kwak, J. H.; Zhu, H.; Lee, J. H.; Peden, C. H. F.; Szanyi, J. Two different cation positions in Cu-SSZ-13? Chem. Commun. 2012, 48, $4758-4760$.

(3) Long, R. Q.; Yang, R. T. Reaction mechanism of selective catalytic reduction of $\mathrm{NO}$ with $\mathrm{NH}_{3}$ over Fe-ZSM-5 catalyst. J. Catal. 2002, 207 (2), 224-231.

(4) Kwak, J. H.; Tran, D.; Szanyi, J.; Peden, C. H. F.; Lee, J. H. The effect of copper loading on the selective catalytic reduction of nitric oxide by ammonia over Cu-SSZ-13. Catal. Lett. 2012, 142 (3), 295301.

(5) Kröcher, O.; Elsener, M. Combination of $\mathrm{V}_{2} \mathrm{O}_{5} / \mathrm{WO}_{3}-\mathrm{TiO}_{2}, \mathrm{Fe}-$ ZSM5, and Cu-ZSM5 catalysts for the selective catalytic reduction of nitric oxide with ammonia. Ind. Eng. Chem. Res. 2008, 47 (22), 8588-8593.

(6) Sandro, B.; Oliver, K.; Arno, T.; Roderik, A. The state of the art in selective catalytic reduction of $\mathrm{NO}_{x}$ by ammonia using metalexchanged zeolite catalysts. Catal. Rev. 2008, 50 (4), 492-531.

(7) Park, J.; Park, H.; Baik, J.; Nam, I.; Shin, C.; Lee, J.; Cho, B.; Oh, S. Hydrothermal stability of CuZSM5 catalyst in reducing $\mathrm{NO}$ by $\mathrm{NH}_{3}$ for the urea selective catalytic reduction process. J. Catal. 2006, 240 (1), 47-57.

(8) Fickel, D. W.; D’Addio, E.; Lauterbach, J. A.; Lobo, R. F. The ammonia selective catalytic reduction activity of copper-exchanged small-pore zeolites. Appl. Catal., B 2011, 102 (3-4), 441-448.

(9) Kwak, J. H.; Tran, D.; Burton, S. D.; Szanyi, J.; Lee, J. H.; Peden, C. H. F. Effects of hydrothermal aging on $\mathrm{NH}_{3}-\mathrm{SCR}$ reaction over $\mathrm{Cu}$ / zeolites. J. Catal. 2012, 287, 203-209.

(10) Heo, I.; Lee, Y.; Nam, I.-S.; Choung, J. W.; Lee, J.-H.; Kim, H.-J. Effect of hydrocarbon slip on NO removal activity of CuZSM5, FeZSM5 and $\mathrm{V}_{2} \mathrm{O}_{5} / \mathrm{TiO}_{2}$ catalysts by $\mathrm{NH}_{3}$. Microporous Mesoporous Mater. 2011, 141 (1-3), 8-15.

(11) Sultana, A.; Nanba, T.; Sasaki, M.; Haneda, M.; Suzuki, K.; Hamada, H. Selective catalytic reduction of $\mathrm{NO}_{x}$ with $\mathrm{NH}_{3}$ over different copper exchanged zeolites in the presence of decane. Catal. Today 2011, 164 (1), 495-499.

(12) Asima, S.; Tetsuya, N.; Masaaki, H.; Hideaki, H. SCR of $\mathrm{NO}_{x}$ with $\mathrm{NH}_{3}$ over $\mathrm{Cu} / \mathrm{NaZSM}-5$ and Cu/HZSM-5 in the presence of decane. Catal. Commun. 2009, 10 (14), 1859-1863.

(13) Deka, U.; Lezcano-Gonzalez, I.; Warrender, S. J.; Picone, A. L.; Wright, P. A.; Weckhuysen, B. M.; Beale, A. M. Changing active sites in $\mathrm{Cu}$-CHA catalysts: deNO $_{x}$ selectivity as a function of the preparation method. Microporous Mesoporous Mater. 2013, 166, 144-152.

(14) Raquel, M.-F.; Manuel, M.; Cristina, F.; Arkady, K.; Avelino, C. Rational direct synthesis methodology of very active and hydrothermally stable Cu-SAPO-34 molecular sieves for the SCR of $\mathrm{NO}_{x}$. Appl. Catal., B 2012, 127, 273-280.

(15) Yang, X.; Wu, Z.; Moses-Debusk, M.; Mullins, D. R.; Mahurin, S. M.; Geiger, R. A.; Kidder, M.; Narula, C. K. Heterometal incorporation in metal-exchanged zeolites enables low-temperature catalytic activity of $\mathrm{NO}_{x}$ reduction. J. Phys. Chem. C 2012, 116 (44), 23322-23331.

(16) Kwak, J. H.; Tonkyn, R. G.; Kim, D. H.; Szanyi, J.; Peden, C. H. F. Excellent activity and selectivity of Cu-SSZ-13 in the selective catalytic reduction of $\mathrm{NO}_{x}$ with $\mathrm{NH}_{3}$. J. Catal. 2010, 275 (2), 187190.

(17) Schmieg, S. J.; Oh, S. H.; Kim, C. H.; Brown, D. B.; Lee, J. H.; Peden, C. H. F.; Kim, D. H. Thermal durability of $\mathrm{Cu}-\mathrm{CHA} \mathrm{NH} \mathrm{N}_{3}$-SCR catalysts for diesel $\mathrm{NO}_{x}$ reduction. Catal. Today 2011, 184, 252-261.
(18) Fickel, D. W.; Lobo, R. F. Copper coordination in Cu-SSZ-13 and Cu-SSZ-16 investigated by variable-temperature XRD. J. Phys. Chem. C 2010, 114, 1633-1640.

(19) Korhonen, S. T.; Fickel, D. W.; Lobo, R. F.; Weckhuysen, B. M.; Beale, A. M. Isolated $\mathrm{Cu}^{2+}$ ions: active sites for selective catalytic reduction of NO. Chem. Commun. 2011, 47 (2), 800-802.

(20) Deka, U.; Juhin, A.; Eilertsen, E. A.; Emerich, H.; Green, M. A.; Korhonen, S. T.; Weckhuysen, B. M.; Beale, A. M. Confirmation of isolated $\mathrm{Cu}^{2+}$ ions in SSZ-13 zeolite as active sites in $\mathrm{NH}_{3}$-selective catalytic reduction. J. Phys. Chem. C 2012, 116 (7), 4809-4818.

(21) Zones, Zeolites SSZ-13 and its method of preparation; U.S. Patent $4544538,1985$.

(22) Zones, S. I. Conversion of faujasites to high-silica chabazite SSZ13 in the presence of N,N,N-trimethyl-1-adamantammonium iodide. J. Chem. Soc., Faraday Trans. 1991, 87 (22), 3709-3716.

(23) Ren, L.; Zhu, L.; Yang, C.; Chen, Y.; Sun, Q.; Zhang, H.; Li, C.; Nawaz, F.; Meng, X.; Xiao, F.-S. Designed copper-amine complex as an efficient template for one-pot synthesis of Cu-SSZ-13 zeolite with excellent activity for selective catalytic reduction of $\mathrm{NO}_{x}$ by $\mathrm{NH}_{3}$. Chem. Commun. 2011, 47 (35), 9789-9791.

(24) Higgins, M. T. a. J. Collection of simulated XRD patterns for zeolites, 5th ed.; Elsevier: Amsterdam, 2007; pp 112-115.

(25) Xue, J.; Wang, X.; Qi, G.; Wang, J.; Shen, M.; Li, W. Characterization of copper species over $\mathrm{Cu} / \mathrm{SAPO}-34$ in selective catalytic reduction of $\mathrm{NO}_{x}$ with ammonia: Relationships between active $\mathrm{Cu}$ sites and de- $\mathrm{NO}_{x}$ performance at low temperature. J. Catal. 2013, 297, 56-64.

(26) Wang, L.; Li, W.; Qi, G.; Weng, D. Location and nature of $\mathrm{Cu}$ species in $\mathrm{Cu} / \mathrm{SAPO}-34$ for selective catalytic reduction of $\mathrm{NO}$ with $\mathrm{NH}_{3}$. J. Catal. 2012, 289, 21-29.

(27) Sjövall, H.; Olsson, L.; Fridell, E.; Blint, R. J. Selective catalytic reduction of $\mathrm{NO}_{x}$ with $\mathrm{NH}_{3}$ over Cu-ZSM-5-The effect of changing the gas composition. Appl. Catal., B 2006, 64 (3-4), 180-188.

(28) Li, J.; Chang, H.; Ma, L.; Hao, J.; Yang, R. T. Low-temperature selective catalytic reduction of $\mathrm{NO}_{x}$ with $\mathrm{NH}_{3}$ over metal oxide and zeolite catalysts-A review. Catal. Today 2011, 175 (1), 147-156.

(29) Ma, L.; Li, J.; Cheng, Y.; Lambert, C. K.; Fu, L. Propene poisoning on three typical Fe-zeolites for $\mathrm{SCR}$ of $\mathrm{NO}_{x}$ with $\mathrm{NH}_{3}$ : from mechanism study to coating modified architecture. Environ. Sci. Technol. 2012, 46 (3), 1747-1754.

(30) Richter, M.; Fait, M.; Eckelt, R.; Schneider, M.; Radnik, J.; Heidemann, D.; Fricke, R. Gas-phase carbonylation of methanol to dimethyl carbonate on chloride-free $\mathrm{Cu}$-precipitated zeolite $\mathrm{Y}$ at normal pressure. J. Catal. 2007, 245 (1), 11-24.

(31) Gao, F.; Walter, E. D.; Karp, E. M.; Luo, J.; Tonkyn, R. G.; Kwak, J. H.; Szanyi, J.; Peden, C. H. F. Structure-activity relationships in $\mathrm{NH}_{3}$-SCR over Cu-SSZ-13 as probed by reaction kinetics and EPR studies. J. Catal. 2013, 300, 20-29.

(32) Kefirov, R.; Penkova, A.; Hadjiivanov, K.; Dzwigaj, S.; Che, M. Stabilization of $\mathrm{Cu}^{+}$ions in BEA zeolite: Study by FTIR spectroscopy of adsorbed CO and TPR. Microporous Mesoporous Mater. 2008, 116 (1-3), 180-187.

(33) Dĕdeček, J.; Wichterlová, B.; Kubát, P. Siting of the $\mathrm{Cu}^{+}$ions in dehydrated ion exchanged synthetic and natural chabasites: a $\mathrm{Cu}^{+}$ photoluminescence study. Microporous Mesoporous Mater. 1999, 32, $63-74$.

(34) Zamadies, M.; Chen, X.; Kevan, L. Study of copper(II) location and adsorbate interaction in CuH-SAPO-34 molecular sieve by electron spin resonance and electron spin echo modulation spectroscopies. J. Phys. Chem. 1992, 96, 2652-2657.

(35) Deka, U.; Lezcano-Gonzalez, I.; Weckhuysen, B. M.; Beale, A. $\mathrm{M}$. Local environment and nature of $\mathrm{Cu}$ active sites in zeolite-based catalysts for the selective catalytic reduction of $\mathrm{NO}_{x}$. ACS Catal. 2013, 3 (3), 413-427.

(36) Narayana, M.; Kevan, L. Detection of a new trigonal bipyramidal copper species in $\mathrm{Cu}-\mathrm{CaX}$ zeolite by electron spin resonance and electron spin echo modulation analysis. J. Chem. Phys. 1983, 78 (6), 3573. 
(37) Herman, R. G.; Flentgelb, D. R. Electron paramagnetic resonance parameters of copper (II) Y Zeolites. J. Phys. Chem. 1978, 82 (6), 720-729.

(38) Yu, J.-S.; Ryoo, J. W.; Kim, S. J.; Hong, S. B.; Kevan, L. Cupric ion species in $\mathrm{Cu}(\mathrm{II})$-exchanged $\mathrm{K}$-Offretite gallosilicate determined by electron spin resonance and electron spin echo modulation spectroscopies. J. Phys. Chem. 1996, 100, 12624-12630.

(39) Wang, J.; Yu, T.; Wang, X.; Qi, G.; Xue, J.; Shen, M.; Li, W. The influence of silicon on the catalytic properties of $\mathrm{Cu} / \mathrm{SAPO}-34$ for $\mathrm{NO}_{x}$ reduction by ammonia-SCR. Appl. Catal., B 2012, 127, 137-147.

(40) Calligaris, M.; Mezzetti, A.; Nardin, G.; Randaccio, L. Crystal structures of hydrated and dehydrated forms of a $\mathrm{Mn}$ (II)-exchanged chabazite. Zeolites 1985, 5, 317-319.

(41) Kieger, S. e.; Delahay, G. e.; Coq, B.; Neveu, B. Selective catalytic reduction of nitric oxide by ammonia over $\mathrm{Cu}$-FAU catalysts in oxygen-rich atmosphere. J. Catal. 1999, 183, 267-280. 